\title{
Combined Clagett procedure, negative pressure therapy, and thoracomyoplasty for treatment of late-onset postpneumonectomy empyema necessitatis
}

\author{
Waldemar Schreiner, Wojciech Dudek, Horia Sirbu \\ Department of Thoracic Surgery, University Hospital of Erlangen, Germany
}

Kardiochirurgia i Torakochirurgia Polska 2015; 12 (3): 259-261

\begin{abstract}
Late-onset post-pneumonectomy empyema necessitatis can occur many years after the surgery and is a life-threatening condition. A 58-year-old male presented with empyema necessitatis 18 years after undergoing pneumonectomy. He was successfully treated with a modified two-stage Clagett procedure and ambulatory negative pressure as the bridge between the stages. The 72-month follow-up was uneventful. The complete obliteration of the rigid and wide residual postpneumonectomy cavity was necessary to avoid re-recurrence of the infection.
\end{abstract}

Key words: negative pressure therapy, postpneumonectomy empyema necessitatis, late-onset empyema.

\section{Introduction}

The late onset of postpneumonectomy empyema (PPE) is a complication that can occur up to 60 years after lung resection, and it represents a diagnostic and therapeutic challenge [1]. A very limited number of reports describing late PPE necessitatis widely extending into the extrathoracic soft tissue or mediastinum have been published to date [2-4].

We present a case of empyema necessitatis successfully treated with a modified Clagett procedure where ambulatory negative pressure therapy (NPT) was applied as a bridge between open window thoracostomy (OWT) and thoracomyoplasty with intrathoracic transposition of a muscle flap combining the subscapularis-teres muscles and the superior part of the latissimus dorsi muscle.

\section{Case study}

A 58-year-old male came to our thoracic unit 18 years after a right pneumonectomy for post-tuberculosis destroyed lung syndrome complicated by aspergillosis. He complained of chest pain and swelling at the thoracotomy site over the previous three weeks. The computerized tomography (CT)

\section{Streszczenie}

Późna postać ropniaka przebijającego (empyema necessitatis) może wystąpić wiele lat po operacji chirurgicznej i stanowi zagrożenie dla życia pacjenta. W pracy przedstawiono przypadek 58-letniego pacjenta, który zgłosił się z tym schorzeniem 18 lat po przejściu pneumonektomii. Został poddany zakończonej sukcesem dwuetapowej procedurze Clagetta oraz terapii podciśnieniowej służącej jako pomost pomiędzy etapami. Okres 72 miesięcy obserwacji pooperacyjnej był niepowikłany. Zamknięcie sztywnej, szerokiej jamy pozostałej po pneumonektomii było konieczne w celu uniknięcia powtórnej infekcji. Słowa kluczowe: terapia podciśnieniowa, ropniak empyema necessitatis po pneumonektomii, późna postać ropniaka.

scan demonstrated a large low-density mass with a peripheral calcification in the right pleural space and bright disruption of the $5^{\text {th }}$ intercostal space within the thoracotomy bed (Fig. 1). Pleural fluid microbiology was positive for Pseudomonas aeruginosa. Flexible bronchoscopy ruled out the presence of a bronchopleural fistula (BPF). A lateral muscle-sparing thoracotomy was performed, and loculated chocolate-coloured smelly effusion was found intraoperatively. After extensive debridement of the right hemithoracic cavity, OWT was performed by partial excision of the fourth and fifth rib from the anterior to the midaxillary line. An NPT Vacuseal system consisting of open-cell polyurethane foam (GranuFoam, KCl Inc., San Antonio, TX, USA) in combination with polyvinyl-alcohol foam (WhiteFoam, $\mathrm{KCl}$ Inc., San Antonio, TX, USA) was applied directly in the pleural space and in the extrathoracic soft tissue.

Negative pressure therapy was initiated with $75 \mathrm{mmHg}$ and subsequently increased to $125 \mathrm{mmHg}$ after five days. The patient was discharged from hospital on the $7^{\text {th }}$ postoperative day to continue the NPT on an outpatient basis. Wound reviews and NPT dressing changes were performed weekly over the following four months. During

Address for correspondence: Waldemar Schreiner, MD, Department of Thoracic Surgery, University Hospital of Erlangen, Krankenhausstr. 12, 91054 Erlangen (Bavaria), Germany, phone: +49 91318532047, e-mail: waldemar.schreiner@uk-erlangen.de 


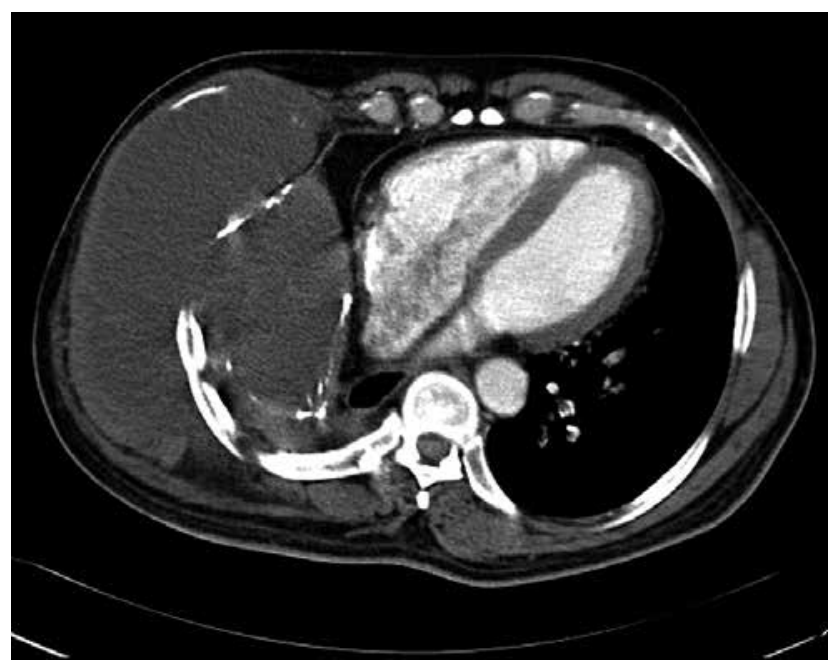

Fig. 1. Computed tomography of the chest (mediastinal window) on admission shows a large low-density mass with peripheral calcification in the right postpneumonectomy cavity disrupting the $5^{\text {th }}$ intercostal space and penetrating into subcutaneous tissue

that time, we provided the patient with enhanced nutritional support.

Subsequently, thoracomyoplasty was performed to achieve definitive obliteration of the residual space and prevent empyema recurrence. The cephalic part of the latissimus dorsi muscle was prepared for intrathoracic transposition. The distal part of the latissimus dorsi muscle could not have been used as a flap due to atrophy resulting from vascular pedicle transsection during the first thoracotomy. A partial scapulectomy was performed, and the subscapularis muscle was released in combination with the teres group. The empyema cavity was obliterated using the latissimus dorsi, the subscapularis, and the teres group muscles. The thoracoplasty (Th2-Th8) was completed by partial subperiosteal rib resection. Finally, the residual space was completely obliterated by using the prepared muscle flaps (Fig. 2). The postoperative course was uneventful, and the patient was discharged home on the $14^{\text {th }}$ postoperative day. The 72-month follow-up control showed a moderate reduction in the range of arm movement with some degree of scoliosis in the cervical-thoracic region, but without signs of persistent infection.

\section{Discussion}

Postpneumonectomy empyema is a rare, potentially life-threatening condition with reported incidence ranging from $2.2 \%$ to $16 \%$. Most PPEs are of early onset and are associated with the occurrence of a BPF. Early PPEs with BPFs are best managed by full thoracotomy or window thoracostomy with evacuation of the infected pleural fluid, debridement and irrigation of the pleural space, closure of the BPF, and filling the sterilised space with an antibiotic solution (Clagett procedure) [5]. Additionally, the debrided and closed bronchial stump may be covered with a vascularised tissue flap (omentum, pericardium, chest wall muscles, or diaphragm). Early PPEs without BPFs can be managed with single-stage lavage or thoracoscopy [6]. The diagnosis of late-onset PPE is difficult as clinical symptoms (fever, anorexia, weight loss, chest pain) are nonspecific, and, in a patient with lung cancer history, they may suggest a recurrence. The majority of late-onset PPEs are diagnosed late in the course of the illness and are associated with increased morbidity. Findings such as a new air-fluid level on a chest radiogram, suggesting a bronchial or oesophageal fistula, or the presence of empyema necessitatis may directly lead to diagnosis. Our patient was septic, and the swelling of his right hemithorax with associated erythema enabled us to establish the diagnosis of empyema necessitatis. The pathogen causing the infection in our patient was identified,
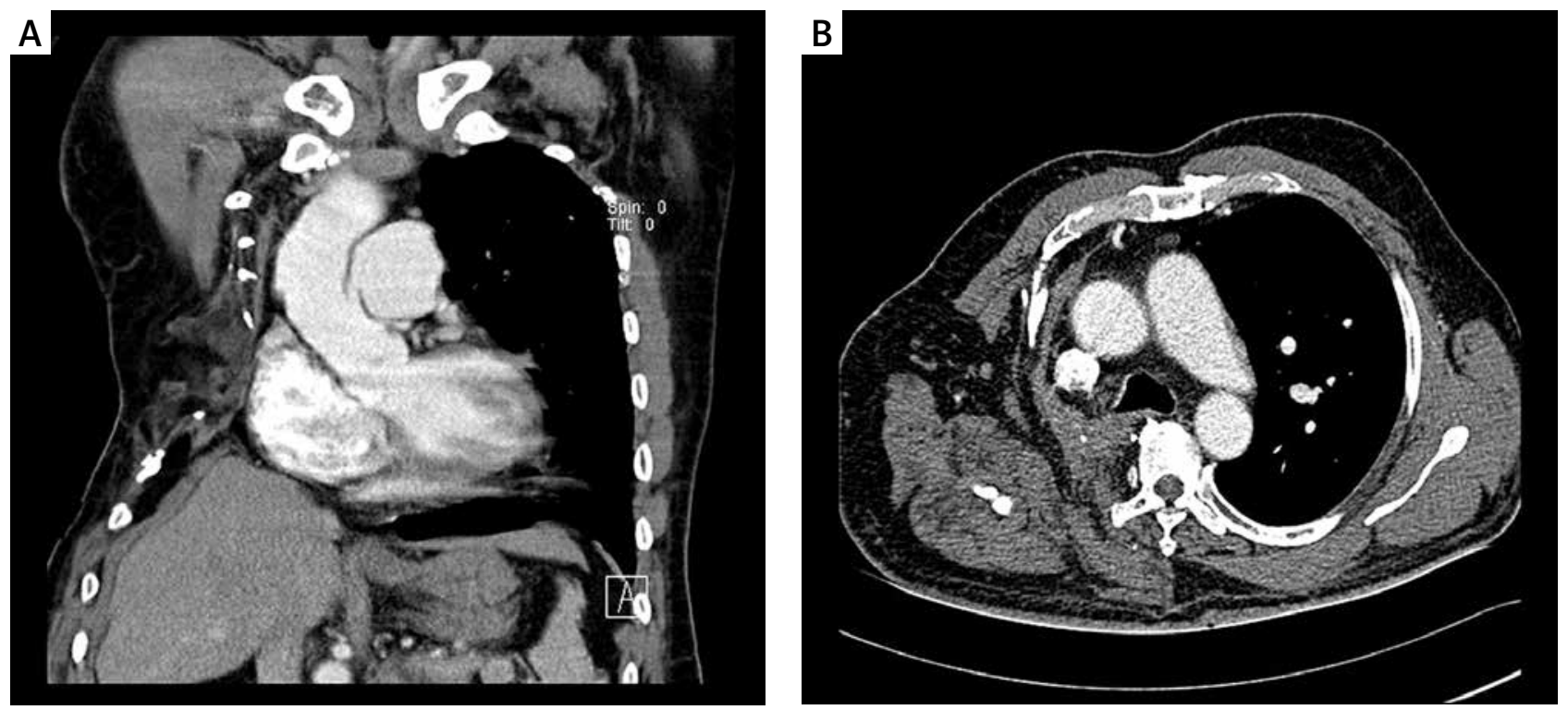

Fig. 2. Computed tomography after thoracomyoplasty with muscle transposition and complete obliteration of the residual postpneumonectomy cavity 
but its source was unknown. The most probable cause was the haematogenous spread of Pseudomonas aeruginosa.

Late PPEs require OWT with drainage of the pleural space, BPF closure, debridement of the pleural space, and obliteration of the pleural space with transposed extrathoracic muscles and/or omentum [ 7,8$]$. In our patient, in whom empyema necessitatis was diagnosed, we modified the Clagett procedure by applying the NPT system as a bridge to reconstructive surgery with a large flap consisting of the latissimus dorsi, subscapularis, and teres muscles. Due to cachexia and the suspected reduced volume of the omentum, we did not use an omental flap to fill the pleural space. The NPT resulted in accelerated treatment of sepsis and enabled local infection control in the pleural cavity and thoracic wall. In less complex cases, without or with very small BPFs, pleural NPT can be applied via minithoracotomy (mini-VAC), with the omission of OWT and thoracomyoplasty. Sziklavari et al. recommend the miniVAC technique for the treatment of pleural empyemas as an alternative to classic decortication in high-risk patients [9]. Schneiter and Grodzki also describe an innovative method of accelerated treatment for both early and late PPEs. They recommend thoracotomy, debridement of the pleural cavity, application of povidone-iodine-soaked towels under negative pressure, elimination of BPF if present, and filling the pleural cavity with an antibiotic solution [10]. In our patient, due to the disruption in the intercostal space and the extended involvement of the extrathoracic soft tissue, we decided to perform standard OWT followed by NPT. The NPT was performed over a prolonged period of four months to achieve optimal sterility of the pleural space and granulation of the wound site. The definitive obliteration of the residual pleural space was achieved by extended thoracomyoplasty.

\section{Conclusions}

Empyema necessitatis as a sequel of late-onset PPE is an uncommon complication requiring a targeted and radical approach. Open window thoracostomy combined with the NPT allowed for optimal sterilisation and reduction of residual pleural space as well as granulation of the wound. Despite the wide extrathoracic extension of the empyema, the long-term NPT was conducted partially in an outpatient setting.

Nutritional build-up of the patient prior to the surgery was crucial in surviving the extensive procedure. The complete obliteration of the rigid and wide residual postpneumonectomy cavity was necessary to avoid a re-recurrence of the infection.

\section{Disclosure}

Authors report no conflict of interest.

\section{References}

1. Pop D, Nadeemy A, Venissac N, Mouroux J. Bronchopleural fistula: the Damocles sword of all pneumectomies. Interactive Cardiovasc Thorac Surg 2011; 13: 107-108.

2. Holden MP, Woller GH. Pus somewhere, pus nowhere else, pus above the diaphragm. Postpneumectomy empyema necessitatis. Am J Surg 1972; 124: 669-670.

3. Fatimi SH, Khalid U, Fatima S, Saleem T. Late onset postpneumectomy empyema presenting 24 years after pneumectomy. J Park Med Assoc 2010; 60: 584-586.

4. Durand M, Godbert B, Anne V, Grosdidier G. Large thoracomyoplasty and negative pressure therapy for the late postpneumonectomy empyema with retrosternal abscess: a modern version of the Clagett procedure. Interact Cardiovasc Thorac Surg 2011; 12: 888-889.

5. Gharagozloo F, Trachiotis G, Wolfe A, DuBree KJ, Cox JL. Pleural space irrigation and modified Clagett procedure for the treatment of early postpneumonectomy empyema. J Thorac Cardiovasc Surg 1998; 116: 943-948.

6. Gossot D, Stern J-B, Galetta D, Debrosse D, Philippe Girard P, Caliandro R, et al. Thoracoscopic management of postpneumonectomy empyema. Ann Thorac Surg 2004; 78: 273-276.

7. Pairolero PC, Arnold PG, Trastek VF, Meland NB, Kay PP. Postpneumonectomy empyema. The role of intrathoracic muscle transposition. J Thorac Cardiovasc Surg 1990; 99: 958-966.

8. Gharagozloo F, Margolis M, Facktor M, Tempesta B, Najam F. Postpneumonectomy and postlobectomy empyema. Thorac Surg Clin 2006; 16: 215-222.

9. Sziklavari Z, Allgäuer M, Hübner G, Neu R, Ried M, Grosser C, Szöke T, Schemm R, Hofmann HS. Minimally invasive vacuum-assisted closure therapy in the management of complex pleural empyema. Interact Cardiovasc Thorac Surg 2013; 17: 49-53.

10. Schneiter D, Grodzki T, Lardinois D, Kestenholz PB, Wojcik J, Kubisa B, Pierog J, Weder W. Accelerated treatment of postpneumonectomy empyema: a binational long-term study. J Thorac Cardiovasc Surg 2008; 136: 179-185. 